Jurnal Indonesia Sosial Teknologi:p-ISSN: 2723 - 6609

e-ISSN : 2745-5254

Vol. 2, No.4 April 2021

\title{
TINJAUAN YURIDIS KEPEMILIKAN HAK ATAS TANAH YANG DIPEROLEH MELALUI PEWARISAN
}

\section{Antonius Ndruru}

Sekolah Tinggi Ilmu Hukum Nias Selatan

Email: antoniusndruru11@gmail.com

\section{Abstract}

Inherited land is land obtained from the distribution of the inheritance of a person who has passed away, which is passed on to his heirs. Land has a very important role in human life, because the more advanced society is, the more densely populated it is, the more important the position of land rights is. Article 20 paragraph (1) Basic Agrarian Law Property rights are the strongest and fullest hereditary rights that can be owned by people over land. Transfer of title to land can occur due to legal events. This study aims to determine and analyze the legal certainty of land obtained through inheritance. The problem that arises is how to obtain land rights through inheritance. This research uses normative legal research with the statutory approach method, the case approach method and the analytical approach method. The technique of data collection is carried out through literature legal materials consisting of primary legal materials, secondary legal materials and tertiary legal materials and then analyzed qualitatively descriptively and deductive conclusions. The Basic Agrarian Law in conjunction with Government Regulation No. 24 of 1997, if a land owner dies, the person who receives the inheritance within 6 (six) months must register the inherited land with the local National Land Agency with the condition that there is a death certificate from the village, proof of identity and a certificate of inheritance made by the Village Head. If the heirs will distribute the inheritance, a deed of distribution of the inheritance must be made to a notary with the conditions that have been determined and then registered or carry out the process of transferring the name to the office of the National Land Agency to make a certificate.

Keyword: ownership of land rights; through inheritance.

\begin{abstract}
Abstrak
Tanah warisan adalah tanah yang diperoleh dari pembagian warisan seseorang yang telah meninggal dunia diwariskan kepada ahli warisnya. Tanah mempunyai peranan sangat penting dalam kehidupan manusia ini, karena semakin maju masyarakat, semakin padat penduduknya, maka akan menambah lagi pentingnya kedudukan hak atas tanah. Pasal 20 ayat (1) Undang-Undang Pokok Agraria Hak milik adalah hak turun temurun, terkuat dan terpenuh yang dapat dimiliki orang atas tanah. Peralihan hak milik atas tanah dapat terjadi karena adanya peristiwa hukum. Penelitian ini bertujuan untuk mengetahui dan menganalisa adanya kepastian Hukum terhadap Tanah yang diperoleh melalui Pewarisan. Permasalahan yang timbul adalah bagaimana cara mendapatkan hak atas tanah melalui Pewarisan. Penelitian ini
\end{abstract}


menggunakan penelitian hukum normatif dengan metode pendekatan peraturan perundang-undangan, metode pendekatan kasus dan metode pendekatan analitis. Teknik pengumpulan data dilakukan melalui bahan hukum kepustakaan yang terdiri dari bahan hukum primer, bahan hukum sekunder dan bahan hukum tersier dan kemudian dianalisis secara kualitatif deskriptif dan penarikan kesimpulan secara deduktif.Berdasarkan hasil penelitian bahwa pelaksanaan peralihan hak milik atas tanah karena pewarisan sesuai dengan Undang-Undang Pokok Agraria juncto Peraturan Pemerintah No. 24 Tahun 1997, apabila seorang pemilik tanah meninggal dunia maka orang yang menerima warisan tersebut dalam kurun waktu 6 (enam) bulan harus mendaftarkan tanah warisannya tersebut ke Badan Pertanahan Nasional setempat dengan syaraat adanya surat kematian dari desa, bukti diri dan surat keterangan waris yang dibuat oleh Kepala Desa. Apabila ahli waris akan membagikan warisan tersebut harus dibuatkan akta pembagian harta warisan ke Notaris dengan syarat-syarat yang telah ditentukan dan selanjutnya didaftarkan atau melakukan proses balik nama kepada kantor Badan Pertanahan Nasional untuk dibuatkan sertifikat.

Kata kunci: kepemilikan hak atas tanah; melalui pewarisan.

\section{Pendahuluan}

Hak milik atas tanah sebagai salah satu jenis hak milik, sangat penting bagi negara, bangsa, dan rakyat Indonesia sebagai masyarakat agraria yang sedang membangun ke arah perkembangan industri dan lain-lain. Istilah Tanah secara yuridis dalam Pasal 4 ayat (1) Undang-Undang Pokok Agraria adalah permukaan bumi atau dengan kata lain kulit bumi (Pasal 4 ayat (1) Undang-Undang Nomor 5, 1960).

Tanah diberikan kepada dan dipunyai oleh orang dengan hak-hak yang disediakan oleh Undang-Undang Pokok Agararia (UUPA), adalah untuk digunakan atau dimanfaatkan (Suryadi et al., 2017). Diberikannya dan dipunyainya tanah dengan hakhak tersebut tidak akan bermakna jika penggunaannya terbatas hanya pada tanah sebagai permukaan bumi saja, akan tetapi dapatdipergunakansebagai tempat mendirikan rumah, tempat bercocok tanam, tempat berusaha bahkan melakukan pengalihan hak atas tanah tersebut melalui perikatan jual beli, hibah dan warisan.

Dalam Pasal 33 ayat (3) Undang-Undang Dasar Negara Republik Indonesia Tahun 1945 menyatakan: "Bumi, air dan kekayaan alam yang terkandung didalamnya dikuasai oleh negara dan dipergunakan sebesar-besarnya untuk kemakmuran rakyat. Hak menguasai dari negara ini juga terdapat dalam Pasal 2 Undang-Undang Pokok Agraria Nomor 5 Tahun 1960 (UUPA) sebagai berikut:

(1) Atas dasar ketentuan dalam pasal 33 ayat (3) Undang-undang Dasar dan hal-hal sebagai yang dimaksud dalam pasal 1, bumi, air, dan ruang angkasa, termasuk kekayaan alam yang terkandung didalamnya itu pada tingkatan tertinggi dikuasai oleh Negara, sebagai organisasi kekuasaan seluruh rakyat.

(2) Hak menguasai dari Negara termaksud dalam ayat (1) pasal ini memberi wewenang untuk: 
a. Mengatur dan menyelenggarakan peruntukan, penggunaan, persediaan dan pemeliharaan bumi, air dan ruang angkasa;

b. Menentukan dan mengatur hubungan-hubungan hukum antara orang-orang dengan bumi, air dan ruang angkasa;

c. Menentukan dan mengatur hubungan-hubungan hukum antara orang-orang dan perbuatan-perbuatan hukum yang mengenai bumi, air dan ruang angkasa.

(3) Wewenang yang bersumber pada hak menguasai dari Negara tersebut pada ayat (2) pasal ini digunakan untuk mencapai sebesar-besar kemakmuran rakyat, dalam arti kebahagiaan, kesejahteraan dan kemerdekaan dalam masyarakat dan Negara hukum Indonesia yang merdeka berdaulat, adil dan makmur.

(4) Hak menguasai dari Negara tersebut di atas pelaksaannya dapat dikuasakan kepada daerah-daerah Swatantra dan masyarakat-masyarakat hukum adat, sekedar diperlukan dan tidak bertentangan dengan kepentingan nasional, menurut ketentuan-ketentuan Peraturan Pemerintah.

Pasal 4 ayat (1) UUPA yaitu atas dasar hak menguasai dari Negara sebagai yang dimaksud dalam pasal 12 ditentukan adanya macam-macam hak atas permukaan bumi yang disebut tanah, yang dapat diberikan kepada dan dipunyai oleh orang-orang, baik sendiri maupun bersama-sama dengan orang lain, serta Badan Hukum (Perdana, 2019). Dengan demikian, jelaslah bahwa tanah dalam pengertian yuridis adalah permukaan bumi, sedangkan hak atas tanah adalah hak atas sebagian tertentu permukaan bumi, yang berbatas, berdimensi dua dengan ukuran panjang dan lebar. Peralihan hak atas tanah dapat dilakukan melalui hibah dan warisan.

Harta warisan selalu meliputi baik aktiva maupun pasiva pewaris. Pasal 833 Kitab Undang-Undang Hukum Perdata (KUHPerdata) mengatakan bahwa sekalian ahli waris dengan sendirinya karena hukum memperoleh hak milik atas segala barang, segala hak dan segala piutang si yang meninggal (Miru A, 2011). Pasal 955 Kitab Undang-Undang Hukum Perdata berbunyi pada saat si yang mewariskan meninggal dunia, sekalian mereka yang dengan wasiat tersebut diangkat menjadi waris, seperti pun mereka yang demi Undang-Undang berhak mewarisi sesuatu bagian dalam warisan, demi Undang-Undang pula memperoleh hak milik atas harta peninggalan si meninggal (Sari \& Parwata, 2016). Dalam suatu keluarga juga ada boedel, boedel keluarga, seperti misalnya harta persatuan, walaupun istilah boedel keluarga lebih jarang digunakan, dalam Pasal 834 KUHPerdata menyatakan bahwa: ahli waris berhak mengajukan gugatan untuk memperoleh warisannya terhadap semua orang yang memegang besit atas seluruh atau sebagian warisan itu dengan hak alas hak ataupun tanpa alas hak, demikian pula terhadap mereka yang dengan licik telah menghentikan besitnya (Purnamasari, 2014). Jadi dapat disimpulkan bahwa barang siapa yang merasa oleh karena kedudukannya sebagai ahli waris berhak untuk menuntut hak-haknya sebagai ahli waris baik secara litigasi ataupun non-litigasi.

Dalam Pasal 19 UU No. 5 Tahun 1960 tentang Peraturan Dasar Pokok-Pokok Agraria (Undang-Undang Pokok Agraria atau disingkat UUPA) dikatakan bahwa 
pendaftaran tanah dimaksudkan untuk memeberikan kepastian hukum dan yang dimaksud dengan kepastian hukum adalah memberikan kepastian hak-hak atas tanah.Adapun cara-cara pendaftaran tanah yang dimaksudkan untuk memberikan jaminan kepastian hak-hak atas tanah

Hak atas tanah yang diperoleh dari negara terdiri dari hak milik, hak guna usaha, hak guna bangunan, hak pakai dan hak pengelolaan. Tiap-tiap hak mempunyai karakteristik tersendiri dan semua harus didaftarkan menurut ketentuan hukum dan perundang-undangan. Salah satu kekhususan dari hak milik adalah hak turun-temurun, terkuat dan terpenuh yang dapat dipunyai orang atas tanah. Hak milik dapat beralih dan diahlikan kepada pihak lain. Salah satu kekhususan dari hak milik ini tidak dibatasi oleh waktu dan diberikan untuk waktu yang tidak terbatas lamanya yaitu selama hak milik ini masih diakui dalam rangka berlakunya Pasal 27 Undang-Undang Pokok Agraria.

Peralihan Hak Milik karena pewarisan terjadi "karena hukum", artinya dengan meninggalnya pemilik tanah, maka ahli warisnya memperoleh Hak Miliknya itu menurut hukum sejak ia meninggal dunia (Harsono, 2007). Pendaftaran peralihan hak yang disebabkan oleh pewarisan, pemohon hanya cukup menyertakan bukti sebagai ahli waris yang sah, yang kesemuanya tertuang dalam fatwa waris, mengapa harus menyertakan bukti penunjukan sebagai ahli waris yang sah? Karena ahli waris berhak secara sah “......menggantikan kedudukan hukum dari orang yang meninggal dalam kedudukan hukum mengenai harta kekayaannya.

Hak milik atas tanah menurut Pasal 20 ayat (1) Undang-Undang Nomor 5 Tahun 1960 Tentang Pokok Pokok Agraria menyatakan "Hak milik atas tanah adalah hak turun-temurun, terkuat dan terpenuh yang dapat dipunyai orang atas tanah" Hak milik turun-temurun artinya dapat diwarisi oleh ahli waris yang mempunyai tanah. Hal ini berarti hak milik tidak ditentukan jangka waktunya seperti misalnya, hak guna bangunan dan hak Guna Usaha. Hak milik tidak hanya akan berlangsung selama hidup orang yang mempunyainya, melainkan kepemilikannya akan dilanjuti oleh ahli warisnya setelah ia meninggal dunia. Tanah yang menjadi obyek hak milik (hubungan hukumnya) itu pun tetap, artinya tanah yang dipunyai dengan hak milik tidak bergantiganti (tetap sama) (Sudrajat, 2011).

Sesuai dengan Pasal 20 ayat (2) UUPA "Hak milik dapat beralih dan dialihkan kepada pihak lain." Peralihan hak milik atas tanah dapat terjadi karena perbuatan hukum dan peristiwa hukum. Peralihan hak milik atas tanah karena perbuatan hukum dapat terjadi apabila pemegang hak milik atas tanah dengan sengaja mengalihkan hak yang dipegangnya kepada pihak lain. Sedangkan peralihan hak milik atas tanah karena peristiwa hukum terjadi apabila pemegang hak milik atas tanah meninggal dunia, maka dengan sendirinya atau tanpa adanya suatu perbuatan hukum hak milik beralih kepada ahli waris pemegang hak. (Budiono, 2010) Peralihan hak milik atas tanah dapat dilakukan dengan cara:

1. Jual beli

2. Tukar Menukar

3. Hibah 


\section{Warisan}

Perolehan Hak Milik atas tanah dapat juga terjadi karena pewarisan dari pemilik kepada ahli waris karena wasiat dari orang yang mewasiatkannya sesuai. Pewarisan dapat terjadi karena ketentuan undang-undang (Sutedi, 2019). Berdasarkan banyaknya perkara yang menyangkut tanah, dapat dilihat bahwa tanah memegang peranan sentral dalam kehidupan dan perekonomian Indonesia (Hartono, 1978). Kasus-kasus yang menyangkut tanah terutama dalam hal sengketa tanah yang terjadi hingga saat ini tidak pernah surut, disebabkan oleh semakin banyaknya pertumbuhan aktifitas manusia dan semakin kompleksnya masalah yang terjadi antara sesama sehingga dapat menimbulkan kecenderungan konflik dan sengketa tanah. Meningkatnya jumlah penduduk yang bertolak belakang dengan kondisi tanah yang tidak mungkin mengalami peningkatan atau perluasan sering memicu timbulnya perbedaan kepentingan berkaitan dengan penggunaan dan pemanfaatan tanah.

Salah satu sengketa peralihan hak milik melalui pewarisan adalah Putusan Pengadilan Tinggi Negeri Medan Nomor 86/Pdt/2018/PT. Mdn yang memenangkan Terbanding sebelumnya Penggugat, membuat tidak terjaminnya kepastian hukum terhadap tanah yang diperoleh melalui pewarisan. Objek sengketa pada mulanya diperoleh Pembanding sebelumnya Tergugat sebagai warisan dari kakek orangtua Pembanding yang diwarisi secara turun-temurun dan seterusnya diwariskan kepada kakek Pembanding dan seterusnya diwariskan kepada orangtua Pembanding.

Objek sengketa dikuasai oleh keluarga Pembanding selama puluhan tahun dibuktikan dengan adanya tanaman pohon karet, pohon mau'so, pohon simalambuo, pohon aren, dan tanaman lainya serta keluarga Pembanding mengelola dan mengusahakan tanah kebun dan mengambil hasil dari tanah tersebut dan tidak ada yang keberatan dan/atau mengklaim sebagai hak miliknya. Bahwa pada tahun 1986 orang tua Terbanding mendatangi orangtua Pembanding untuk meminta tolong agar memberikan izin sementara kepada orangtua Terbanding untuk mengelola dan mengusahakan sebagian objek sengketa milik orangtua Pembanding, danorangtua Pembanding memberikan izin dikarenakan orangtua Terbanding tidak lain adalah keluarga orangtua Pembanding (Iparnya orangtua Pembanding).

Orangtua Pembanding meninggal dunia pada tahun 1993, dan Pembanding sebagai ahli waris meninggalkan desa merantau untuk mencoba keberuntungan dalam mencari nafkah. Setelah Pembanding merasakan pahitnya hidup dirantau, Pembanding memutuskan kembali ke Desa untuk mengelola dan mengusahakan tanah objek sengketa, namun dilarang oleh Terbanding.Terbanding mengklaim bahwa objek sengketa merupakan miliknya. Bahwa sebelumnya pada tahun 2006 saudara Ayah Pembanding, telah melarang Terbanding agar tidak mendirikan rumah di atas tanah tersebut, sebab objek sengketa masih milik Pembanding sebagai ahli waris, namun atas permintaan Ibu Terbanding (saudari kandung orangtua Pembanding) mengatakan bahwa hanya untuk sementara saja dan rumah yang didirikan akan dibongkar setelah sudah ada pengganti atau sudah ada rumah baru Terbanding. Berdasarkan uraian tersebut, maka penulis tertarik untuk melakukan penelitian yang akan dituangkan dengan judul, 
Tinjauan Yuridis Kepemilikan Hak Atas Tanah yang diperoleh melalui Pewarisan. Adapun tujuan dari penelitian ini adalah untuk mengetahui dan menganalisa adanya kepastian hukum terhadap kepemilikan hak atas tanah yang diperoleh melalui pewarisan.

\section{Metode Penelitian}

Dalam penelitian ini menggunakan jenis penelitian hukum normatif dengan mengumpulkan data sekunder yang terdiri dari bahan hukum primer, bahan hukum sekunder dan bahan hukum tersier, kemudian metode pendekatan yang digunakan adalah pendekatan peraturan perundang-undangan (statute approach) dan pendakatan kasus (case approach), serta pendekatan analitis (analytical approach). Teknik pengumpulan data dilakukan melalui penelusuran data kepustakaan (library research), dan untuk penarikan kesimpulan dilakukan secara kualitatif deskriptif dengan konsep secara logis, sistematis, dan koheren yaitu dengan mendeskripsikan serta menguraikan isu hukum mengenai peralihan hak milik atas tanah melalui Pewarisan (Mukti Fajar \& Achmad, 2010).

\section{Hasil dan Pembahasan}

Hak milik atas tanah menurut Pasal 20 ayat (1) Nomor 5 Tahun 1960 Tentang Undang-Undang Pokok Agraria menyatakan " Hak milik atas tanah adalah hak turun temurun, terkuat dan terpenuh yang dapat dipunyai orang atas tanah, hak milik tidak hanya berlangsung selama hidup orang yang mempunyainya, melainkan kepemilikannya akan dilanjuti oleh ahli warisnya setelah ia meninggal dunia (Muljadi, 2020). Sesuai dengan Pasal 20 ayat (2) UUPA "Hak milik dapat beralih dan dialihkan kepada pihak lain." Peralihan hak milik atas tanah dapat terjadi karena perbuatan hukum dan peristiwa hukum. Peralihan hak milik atas tanah karena perbuatan hukum dapat terjadi apabila pemegang hak milik atas tanah dengan sengaja mengalihkan hak yang dipegangnya kepada pihak lain. Sedangkan peralihan hak milik atas tanah karena peristiwa hukum, terjadi apabila pemegang hak milik atas tanah meninggal dunia (Isnaeni, 2016).

Putusan Pengadilan Tinggi Negeri Medan Nomor 86/Pdt/2018/PT. Mdn yang memenangkan Terbanding sebelumnya Penggugat, membuat tidak terjaminnya kepastian hukum terhadap tanah yang diperoleh melalui pewarisan. Hasil penelitian terhadap perkara perdata dalam putusan Pengadilan Tinggi Medan Nomor 86/Pdt/2018/PT. Mdn maka dapat dilakukan suatu analisis sebagai berikut :

1. Majelis Hakim Pengadilan Tinggi Medan kurang cermat mempertimbangkan dasar gugatan para Penggugat/Terbanding, dimana para Penggugat/Terbanding menyebutkan objek sengketa sebagai warisan yang diperoleh dari orangtua para Penggugat (suami Penggugat I dan orangtua Penggugat II dan Penggugat III) dan telah dikuasai sejak Tahun 1980 sebagaimana diuraikan dalam pertimbangan hukum Majelis Hukum Pengadilan Negeri Gunungsitoli. 
2. Pada dasarnya putusan Pengadilan harus mampu dan berani tampil menyuarakan keadilan dengan mempertimbangkan bukti-bukti yang ada di persidangan.

3. Pengadilan dalam melaksanakan fungsi dan tugasnya harus sesuai dengan Paraturan Peradilan tidak hanya menjadi mesin undang-undang, tetapi juga mampu mengamati kehidupan masyarakat secara nyata. Sesungguhnya putusan Hakim diperlukan untuk menyelesaikan suatu perkara yang diajukan ke pengadilan.

4. Putusan Hakim harus dapat menyelesaikan perkara yang diajukan, jangan sampai justru memperuncing masalah, bahkan justru menimbulkan kontrovensi di kalangan praktisi hukum maupun masyarakat.

Berdasarkan putusan Hakim Nomor 86/Pdt/2018/PT. Mdn. Menurut Penulis tidak mencerminkan asas keadilan dan asas kepastian hukum dan asas kemanfaatan bagi para Pembanding/Tergugat juga masyarakat pada umumnya. Suatu Putusan yang mengandung keadilan, sulit dicari tolak ukurnya bagi pihak-pihak yang bersengketa, adil bagi satu pihak, belim tentu dirasakan adil oleh pihak lain. Hakim mempunyai tugas menegakkan keadilan, hal ini sesuai dengan kepala putusan yang berbunyi "Demi Keadilan Berdasarkan Ketuhanan Yang Maha Esa" dalam pelaksanaan putusan hukum yang mencerminkan keadilan, penulis menganalisis putusan Nomor 86/Pdt/2018/PT.Mdn, tidak mencerminkan perlindungan hukum terhadap perbandingan atas tanah yang diperoleh melalui pewarisan, sebaikmya Majelis Hakim memutuskan dalam putusanya bahwa Pembanding (tergugat asal) yang menjadi ahli waris dalam perkara perdata ini, bukan Terbanding (Penggugat asal) karena Terbanding (Penggugat asal) bukan penduduk asli kampung Tuhemberua melainkan dari Desa Lologolu. Terbanding tinggal di Desa Tuhemberua karena menikah dengan adik kandung Eliasa Gulo Als Ama Urusa (orang tua kandung para Pembanding. maka jelas dan terbukti bahwa Terbanding tidak memiliki harta warisan di Desa Tuhemberua.

Putusan Hukum akan mencerminkan kemanfaatan, manakala Hakim tidak saja menerapkan hukum secara tekstual belaka dan hanya mengejar keadilan semata, akan tetapi juga mengarah kepada kemanfaatan bagi kepentingan pihak-pihak yang berperkara dan kepentingan masyarakat pada umumnya (Harefa, 2018). Artinya Hakim dalam menerapkan hukum, hendak mempertimbangkan hasilnya nanti, apakah putusan Hakim tersebut membawa manfaat atau kegunaan bagi semua pihak. Hakim diharapkan dalam menerapkan undang-undang yang ada didasarkan pada tujuan atau manfaatnya bagi yang berperkara dan masyarakat. Analisis penulis bahwa putusan Majelis Hakim Kurang cermat atau teliti dengan menjadikan ahli waris Terbanding (Penggugat asal) yang tidak mempunyai dasar kuat atau bukti menjadi ahli waris dalam sengketa tanah waris ini, maka tidak mencerminkan asas kemanfaatan bagi Pembanding dan masyarakat pada umumnya.

Hakim dalam menyelesaikan perkara perdata di pengadilan, mempunyai tugas untuk menemukan hukum yang tepat. Hakim, dalam menemukan hukum tidak cukup mencari dalam undang-undang, tidak mengatur secara jelas dan lengkap, sehingga Hakim harus mengali nilai-nilai hukum yang dalam masyarakat, nilai yang hidup dalam masyarakat tidak lain hukum adat dan hukum tidak tertulis. Hakim bertugas sebagai 
pengalinya dan merumuskannya dalam suatu putusan. Putusan Hakim merupakan bagian dari proses penegakkan hukum yang bertujuan untuk mencapai salah satunya kebenaran hukum atau demi terwujudnya kepastian hukum. Kepastian hukum yang dituangkan dalam putusan Hakim merupakan hasil yang didasarkan pada fakta-fakta persidangan yang relevan secara yuridis serta dipertimbangkan dengan hati nurani.

Perkara perdata sengketa tanah yang diperoleh melalui pewarisan dalam putusan Nomor 86/Pdt/2018/PT.Mdn, tidak ada kepastian hukum terhadap Pembanding atau Tergugat dimana didalam pasal 20 ayat(1) No. 5 Tahun 1960 Tentang Undang-Undang Pokok Agraria menyatakan "hak milik atas tanah adalah hak turun temurun, terkuat dan terpenuh yang dapat dipunyai orang atas tanah" semestinya Majelis Hakim mempertimbangkan dasar hak kepemilikan yang diajukan oleh Pembanding atau Tergugat untuk memdapatkan kepastian hukum bagi Pembanding maupun masyarakat yang mencari keadilan di sidang pengadilan.

\section{Kesimpulan}

Berdasarkan hasil penelitian, maka yang menjadi kesimpulan penulis adalah sebagai berikut :

Pewarisan dapat terjadi karena ketentuan undang-undang ataupun karena wasiat dari orang yang mewasiatkan. Pewarisan hak atas tanah tidak hanya terjadi karena ketentuan peraturan perundang undangan, atau karena adanya surat wasiat yang dibuat oleh pemegang hak atas tanah akan tetapi peralihan hak atas tanah atau Hak Milik dari pemegang haknya kepada pihak lain dapat terjadi karena peristiwa hukum, yaitu meninggal dunianya pemegang hak atas tanah. Dengan meninggal dunianya pemegang hak atas tanah atau Hak Milik maka hak atas tanah atau Hak Milik tersebut berpindah kepada ahli warisnya. Kepemilikan hak milik atas tanah yang diperolah melalui pewarisan dalam Putusan Nomor 86/Pdt/2018/PT. Mdn tidak mencerminkan kepastian hukum dimana karena Hakim dalam menjatuhkan putusan tersebut tidak cermat. Dalam perkara gugatan tersebut Hakim memutuskan Pembanding (tegugat asal) atas kepemilikan hak atas tanah yang diperoleh melalui pewarisan, seharusnya Majelis Hakim mempertimbangkan bukti-bukti dan keterangan para saksi yang diajukan oleh pembanding sesuai fakta-fakta yang terungkap di dalam persidangan.

\section{Bibliography}


5, P. 4 ayat (1) U.-U. N. (1960). Pasal 4 ayat (1) Undang-Undang Nomor 5.

A, M. (2011). Hukum Kontrak dan Perancangan Kontrak. Raja Grafindo Persada.

Budiono, H. (2010). Hukum Perjanjian dan Penerapannya di bidang kenotariatan. Bandung: Citra Aditya Bakti.

Harefa, A. (2018). KEWENANGAN PENYIDIK DALAM PENANGANAN TINDAK PIDANA NARKOBA DI WILAYAH HUKUM KOTA GUNUNGSITOLI. Jurnal Education and Development, 4(1), 37.

Harsono, B. (2007). PPAT sejarah tugas dan kewenangannya. Majalah Renvoi, 8.44.

Hartono, C. F. G. (1978). Beberapa pemikiran kearah pembaharuan hukum tanah. Alumni.

Isnaeni, M. (2016). Hukum Benda dalam Burgerlijk Wetboek. PT Revka Petra Media, Surabaya.

Mukti Fajar, N. D., \& Achmad, Y. (2010). Dualisme penelitian hukum: normatif \& empiris. Pustaka pelajar.

Muljadi, K. (2020). Perikatan yang lahir dari perjanjian. Rajawali pers.

Perdana, M. P. (2019). Legal Consequences of the Marriage Agreement Made by Notaries, Then Not Registered. Authentica, 2(2), 95-120.

Purnamasari, I. D. (2014). Kiat-Kiat Cerdas, Mudah, dan Bijak Memahami Masalah Hukum Waris. Bandung: Kaifa, Bandung.

Sari, P. P., \& Parwata, I. G. N. (2016). Perlindungan Hukum Para Pihak Dalam Perjanjian Bisnis Franchise. Kertha Semaya: Journal Ilmu Hukum, 6(2).

Sudrajat, T. (2011). Perlindungan Hukum Terhadap Hak Anak Sebagai Hak Asasi Manusia Dalam Perspektif Sistem Hukum Keluarga Di Indonesia. Kanun Jurnal Ilmu Hukum, 13(2), 111-132.

Suryadi, S., Ali, D., \& Mansur, T. M. (2017). Dana Titipan Yang Tidak Diketahui Ahli Waris Pemiliknya di Baitul Mal Kota Banda Aceh. Syiah Kuala Law Journal, 1(3), 132-149.

Sutedi, A. (2019). Peralihan hak atas tanah dan pendaftarannya. Sinar Grafika. 